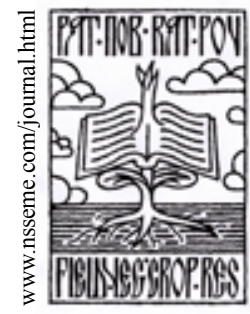

\title{
Growing Cabbage As a Double Crop in Serbia
}

\author{
Janko Červenski • Adam Takač
}

received: 29 November 2011. accepted: 2 February 2012.

(c) 2012 IFVC

doi: $10.5937 /$ ratpov $49-1228$

\begin{abstract}
Summary: Cabbage is an important vegetable crop that is grown at 20,891 ha in Serbia. Growing cabbage as a double crop intensifies land use and increases the profitability of crop production. Double cropping of cabbage is a well-established practice in Serbia. Domestic cultivars and populations of cabbage predominate in the commercial production and this choice of assortment dictates the subsequent use of the harvested cabbage crop. The two main types of use are fresh consumption and pickling. Under Serbian growing conditions, the optimum time for late cabbage transplanting is the first half of July, a period characterized by high temperatures and insufficient and unevenly distributed rainfall. Growing cabbages during this period without the help of irrigation is a fairly risky proposition. Late cabbage cultivars and hybrids must be harvested before temperatures drops below $-5^{\circ} \mathrm{C}$. Cabbage can survive temperatures of $-4^{\circ} \mathrm{C}$ to $-5^{\circ} \mathrm{C}$ for only a limited period of time and prolonged exposure to such conditions will result in the plant being winterkilled and the head losing its market value.
\end{abstract}

Key words: cabbages, cultivation, double cropping

\section{Introduction}

Cabbage is an important vegetable crop in Serbia with total acreage of 20,891 ha. The production is concentrated in Central Serbia (16,860 ha) while 4,031 ha are planted to cabbage in the Vojvodina Province (Republicki zavod za statistiku 2011). Early, medium-season and late cabbage cultivars are grown.

Growing cabbage as a double crop after cereals intensifies land use and increases the profitability of crop production (Maksimović et al. 2008). Vegetable crops such as green beans, cabbage, kale, gherkins and garden beets are successfully double cropped, bringing high yields while simultaneously leaving a considerable acreage for production of field crops (Vučić 1981).

As a foodstuff, cabbage can be prepared as a main dish or salad. It is used year round, either fresh or as sauerkraut. Cabbage can be used or preserved in a number of different ways: it can be pickled, marinated, dried, canned or frozen (Červenski et al. 2003).

Double cropping of cabbage is a long-practised production method in Serbia. Domestic cultivars and populations predominate in the commercial

J. Červenski • A. Takač

Institute of Field and Vegetable Crops, Maksima Gorkog 30, 21000

Novi Sad, Serbia

e-mail: janko.cervenski@ifvcns.ns.ac.rs production, which determines the methods of cabbage use - primarily fresh but production of sauerkraut has intensified in the recent years (Červenski et al. 2011). The impetus to cabbage pickling was given by the domestic late cultivar Futoški. Sauerkraut made of the cultivar Futoški has been certified as a produce with protected geographic origin (Cvetković et al. 2008).

Production of double crops, especially vegetables, is practically impossible without irrigation because summer droughts are frequent and typically occurr on alternate years. Droughts due to insufficient rainfall reach their peak in July and August (Maksimović et al. 2008).

The optimum time for late cabbage transplanting in the agro-climatic conditions of the Vojvodina Province, Serbia is the first half of July. Since this period is characterized by high temperatures and lack or erratic rainfall, cabbage production without irrigation is risky. To achieve high yields of cabbage it is necessary to maintain optimum soil moisture (Karagić et al. 2001).

The lower limit of optimum soil moisture for late cabbage grown in southern Bačka is 70-75\% FWC. Late cabbage is typically grown after small grains, winter barley or wheat. However, harvest

Acknowledgement: This paper has resulted from research on the project TR 31030 "Development of vegetable cultivars and hybrids intended for outdoor and indoor production" financed by the Serbian Ministry of Education and Science. 
is often carried out later in irrigated field than in dry farmed fields, which can bring in question the planting of a double crop (Karagić et al. 2001).

Cabbage forms a large aboveground part while its root system is shallow and poorly developed. Because the roots have a low capacity for water uptake, cabbage requires high soil moisture throughout the growing season. According to Karagić (1998), the average evapotranspiration of cabbage grown on the chernozem soils is about $400 \mathrm{~mm}(380-410 \mathrm{~mm})$. The irrigation practice is scheduled in several turns, with irrigation doses calculated by the bioclimatic method or by the hydrophytothermic index (Maksimović et al. 2006), which is 0.20 and which should be multiplied with the mean daily air temperature to obtain the daily water requirement of the cabbage.

\section{Agroclimatic Conditions Needed for Cabbage Production}

In addition to the genetic constitution of cabbage, which is decisive for head formation, there are environmental factors that significantly affect the formation of cabbage heads (Červenski et al. 2002).

\section{Temperature requirements}

The optimum temperatures for cabbage growth and development range from $15^{\circ} \mathrm{C}$ to $18^{\circ} \mathrm{C}$. Daily temperatures over $25^{\circ} \mathrm{C}$ combined with a dry period result in the formation of small plants with fewer leaves in the rosette and heads with a long internal stem. Daily temperatures above $25^{\circ} \mathrm{C}$ and frequent irrigations result in the formation of more robust plants with many leaves but loose heads.

\section{Water requirements}

$75 \mathrm{~m}^{3}$ of water are needed to produce one ton of cabbage. Cabbage needs 350-420 mm of water during the growing season. A part of the explanation for such high water requirement is in the cabbage root system, which is poorly developed and located mostly at a depth of 10$30 \mathrm{~cm}$. Also, cabbage prefers high soil moisture, which makes it a hydrophilic plant. Finally, the cabbage root system has a weak suction force, does not take up water efficiently and spends the consumed water uneconomically.

\section{Soil requirements}

The production of cabbage requires deep, alluvial humic, medium heavy, sandy clay soils with a $\mathrm{pH}$ reaction from 5.5 to 7.5 . Acid soils should be avoided as they foster the development of clubroot caused by Plasmodiophora brassicae. The disease prevents head forming thus causing a complete crop failure. Infected fields must be relegated to special crop rotations, which should omit all crucifers in the following 5-10 years. When a field is deemed suitable for cabbage production, soil samples should be taken for chemical analysis.

\section{Cultivation Practices Used in Cabbage Production}

Being an intensive vegetable crop, cabbage comes at the beginning of the rotation. This means that it is treated with manure. Monoculture should be avoided and cabbage should be grown at 3- to 5-year intervals. If a field is well tended and the crops are healthy, a three-year rotation is sufficient. If diseases and pests occur due to inadequate cultivation practices, a five-year rotation is recommended. Wheat, early pea, pulses and young potatoes are best previous crops for late cabbage.

Regarding soil preparation, deep plowing at 30 $\mathrm{cm}$ should be performed in autumn, or a plowing at $15-20 \mathrm{~cm}$ in summer. One disking and a seedbed preparation are performed in spring. Three to four between-row cultivations are needed during the growing season.

Cabbage is a potassium-loving plant which takes up more potassium than any other nutrient. It is recommended to fertilize cabbage with the NPK formulation 8:16:24 in the amount of 800 $\mathrm{kg} \mathrm{ha}^{-1}$. Top dressing should be done with AN in the amount of $200 \mathrm{~kg} \mathrm{ha}^{-1}$ after transplanting. It is also advisable to add manure before primary tillage. Manure should be added in the amount of 30-40 tha to humus soils or $40-60 \mathrm{t} \mathrm{ha}^{-1}$ to poorer soils.

Production of transplants in open-cold beds should not be attempted before 25 May. Sowing after this date fits optimally the autumn type of cabbage production. Seedlings are ready for transplanting in mid-July, which is the optimum period for late cabbage planting. The exact date of planting is determined according to the date of transplanting. When grown under optimum conditions, late cabbage transplants mature in 35-40 days (Červenski et al. 2009).

It is recommended to use new and certified seed from undamaged, original packages. Old seed of uncertain origin should be avoided for viability and health reasons.

When buying cabbage seed, it is important to purchase declared seed in original packaging, produced in previous growing season. The declaration should be legible and it should contain all relevant seed quality data specified by the 
seedlaw of the Republic of Serbia. The seed should belong to cabbage varieties or hybrids that have been officially approved by the Department for Varietal Approval of the Ministry of Agriculture, Forestry and Water Management and entered in the List of Approved Varieties (Republika Srbija 2011).

It is advisable to add the NPK formulation 15:15:15 into the soil before planting, in the amount of $0.5 \mathrm{~kg}$ per $10 \mathrm{~m}^{2}$ (Matotan 2008).

If seeds are to be planted in rows, rows should be marked at $10-30 \mathrm{~cm}$ distance prior to seed placement. If seeds are broadcast, 8-10 g of seeds are required per $1 \mathrm{~m}^{2}$ of seed bed in the case when transplants are intended to be replanted. If the seedlings are planted at final row distance, about $3 \mathrm{~g}$ of seed are needed per $\mathrm{m}^{2}$. For one hectare of cabbage, $400 \mathrm{~g}$ of seed are needed. From 250 to 350 seeds are contained in one gram. Up to 500 cabbage seedlings can be raised per square meter (requiring about $2.5 \mathrm{~g}$ of seeds). Sowing depth should be $1-2 \mathrm{~cm}$, since deeper planting prolongs the germination period, which adversely affects the seedlings. For raising late cabbage transplants, 2.5-3 g of seed are needed per $\mathrm{m}^{2}$. During cabbage transplants raising, attention should be paid to proving proper lighting, i.e. plant stand must be taken into account. If the stand is too thick, shading may lead to undesirable elongation of seedlings.

In container nursery production, containers and pots of different sizes are used $-35 \mathrm{~cm}^{3}, 50$ $\mathrm{cm}^{3}, 90 \mathrm{~cm}^{3}$. Cabbage seedlings grow best in 90 $\mathrm{cm}^{3}$ containers. Ready-to-use substrates reduce the use of chemical soil disinfectants, increasing the health safety of the final product (Mišković et al. 2009).

When selecting plants for transplanting, we choose well-developed, healthy plants, with four to six true leaves and intact growing point. Transplants are never pulled out but dug out with a shovel, to avoid root damage. Before planting, transplants are kept in boxes filled with wet straw. It helps root regeneration and mitigates transplant shock. Transplanting is followed by irrigation. Empty spaces are replanted three to five days after transplanting.

Cabbage crop care includes irrigation, fertilization, between-row cultivation and control of diseases, weeds and pests. Critical periods regarding water supply are transplanting and head forming. The lower limits of optimum moisture before and after the beginning of head forming are $80 \%$ and $70 \%$ of FWC, respectively. Late cabbage should be irrigated at 8-12-day intervals, with $30-40 \mathrm{~mm}$ of water. Between-row cultivation is recommended several days after irrigation. This practice helps to maintain soil moisture, control weeds and aerate the soil.

Two weeks after transplanting, cabbage may be fertilized with $100 \mathrm{~kg} \mathrm{AN} /$ ha. Second dressing should be organized just before the rows are closed, while tractor can still pass through the field.

It is important that cabbage transplants are not produced in a plot that had been used for transplant production the previous year or that had been planted to crucifers (cabbage, kale, cauliflower, broccoli, etc.) in previous years. If this recommendation is disregarded, there is a high risk of certain cabbage diseases and pests occurrence. The diseases that typically occur in seedling production in monoculture are black rot (Xanthomonas), clubroot (Plasmodiophora brassicae), seedling damping-off (Pythium) and dry rot (Botrytis). These diseases are difficult to control and the infected soil remains contaminated with up to five years.

The most frequent pests of cabbage seedlings are cabbage beetles, cabbage moths and white cabbage butterflies.

Cabbage diseases and pests are usually transmitted by plant residues from a previous crop. Cabbage is quite sensitive to the transmitted diseases and pests and, therefore, cabbage monoculture should be avoided and a 3- to 5 -year crop rotation should be implemented. Each disease or pest of cabbage occurs under specific conditions and all of them are relatively successfully controlled. A professional approach to the problem of cabbage protection is recommended. It is worthwhile to correctly determine the pathogen, the method and means of its control. Pre-harvest interval and seller's permit in the Republic of Serbia should be taken into account when deciding which chemical to use. We place emphasis on these two facts because cabbage is a food item that often goes directly from the field to the table.

Cabbage harvest requires maximum attention. This is the last operation in the production of cabbage and should be done as carefully as possible. Harvest method determines not only the appearance but also the storability of the heads. If the harvest is not performed in accordance with the technological and production requirements of a particular cabbage cultivar, the quality of the head decreases, as well as its shelf life. The profitability of production decreases proportionally. Therefore, every cabbage grower should be fully acquainted with the technology of cabbage production and cultivation practices 
required to obtain healthy heads of superior quality.

Poor head compaction is a problem encountered by all cabbage growers. This undesirable characteristic is often attributed to the plant itself, disregarding the facts that the cabbage crop is frequently grown under unfavorable conditions and that cultivation practices are inadequately applied or omitted altogether, resulting in loose heads. Furthermore, due to a pressure from the market on one side and weather conditions and cultivation practices applied on the other, cabbage harvest is frequently performed in a single turn. Also, harvested heads are not handled with due care. When all these facts are added up, cabbage heads simply do not have optimal conditions for proper formation. It is essential to adapt cultural practices to each growth stages of cabbage, especially leaf folding and harvest, which determine head compaction (Cervenski et al. 2008).

Cabbage hybrids and cultivars differ in maturation time. Hybrids are harvested mostly in a single turn, when $80-90 \%$ of heads are tightly packed and there are no cracked heads because of thick leaves. The moment of technological maturity is determined differently in the case of cultivars. Heads of cabbage cultivars mature over a time interval, so that the harvest has to be organized differently from the harvest of cabbage hybrids. The technological maturity of a cultivar is stretched over a period of 2-3 weeks and the harvest has to be done in several turns (Červenski 2010).

Harvest of cabbage heads starts when heads are hard to the touch or when the first outer leaf cracks slightly (not the whole head). When several heads in the field show these signs, it is an indication that $30-40 \%$ of the heads are technologically mature. The early cabbage cultivars are harvested 2-3 times, the medium and late ones are harvested 1-2 times. Among other things, the length of technological maturity of cabbage depends on the ambient temperature. It is short in summer and longer in autumn. Second harvest can be organized 10-14 days after the first one. The time of the last third harvest depends on climatic conditions, especially rain, and it takes place a week or two after the second harvest (Červenski et al. 2010).

In the case of late varieties and hybrids of cabbage, their harvest should be completed before the temperatures drop below $-5^{\circ} \mathrm{C}$. Cabbage may be kept for a limited time at $-4^{\circ} \mathrm{C}$ to $-5^{\circ} \mathrm{C}$, but long exposure to low temperatures leads to freezing and loss of market value of cabbage heads (Červenski et al. 2004).

\section{Conclusion}

Cabbage is not only a staple crop but also a major foodstuff in Serbia. Cabbage production should be maintained at least at the level of the current acreage, along with continual improvements of cultivation practices, irrigation, fertilization and crop protection, in order to produce quality heads possessing the lowest possible contents of pesticides and heavy metals. Double cropped cabbage is typically grown for pickling. This should be kept in mind when choosing suitable varieties/hybrids and appropriate cultivation practices. Unfortunately, we have to mention here that it does happen at times that sauercraut smells of pesticides, because crop protection was inexpertly performed. Production of cabbage with a minimum of protection is possible if growers adhere to the recommended cultivation practices and methods of pesticide application. 


\section{References}

Cvetković B, Bardić Ž, Jokanović M, Mastilović J (2008): Technological quality of biofermented white cabbage, cultivar Futoški. Food Processing, Quality and Safety 35: 93-97

Červenski J, Gvozdenović Dj, Gvozdanović-Varga J, Vasić M, Takač A (2002): Effect of genotype x environment interaction on yield components in cabbage (Brassica oleracea var. capitata L.) Acta Horticulturae 579: 57

Červenski J, Bugarski D, Gvozdanović-Varga J (2003): Nutritivna vrednost kupusa. 1. Međunarodni simpozijum "Hrana u 21 veku", Subotica, Zbornik radova, 648-652

Červenski J, Gvozdenović Đ, Bugarski D, Gvozdanović-Varga J (2004): Proizvodnja kasnog kupusa, Zbornik referata 28. Seminara agronoma, Zlatibor, 245

Červenski J, Takač A, Bugarski D, Jovičević D (2008): Zašto se pojavljuje rastresitost glavice kod kupusa? Zbornik radova Instituta za ratarstvo i povrtarstvo Novi Sad, 45: 203-207

Červenski J, Gvozdenović Đ, Gvozdanović-Varga J, Kondić S (2009): Tehnologija proizvodnje rasada za kasnu proizvodnju kupusa. Zbornik radova Instituta za ratarstvo i povrtarstvo Novi Sad, 46: 229-234

Červenski J, Gvozdenović Đ, Vlahović B, Bošnjak Dj, Vračar Lj (2010): Berba i čuvanje kupusa, Ratar. Povrt. 47: 357-362

Červenski J (2010): Gajenje kupusa - monografija. Tampograf, Novi Sad

Červenski J, Gvozdanovic-Varga J, Glogovac S, (2011): Domestic cabbage (Brassica oleracea var. capitata L.) populations from
Serbian province of Vojvodina. African J. Biotechnol. 10: 5281-5285

Karagić Đ (1998): Evapotranspiracija, prinos i kvalitet kupusa u zavisnosti od predzalivne vlažnosti zemljišta i roka sadnje. Magistarska teza, Poljoprivredni fakultet, Novi Sad

Karagić Đ, Dragović S, Maksimović L (2001): Prinos i evapotranspiracija kupusa u zavisnosti od roka sadnje. Zbornik radova 1. Međunarodnog simpozijuma „Hrana u 21. veku”, 14-17. novembar 2001, Subotica, Jugoslavija, 125-131

Maksimović L, Karagić Đ, Bošnjak Đ (2006): Određivanje bioklimatskih koeficijenata kupusa. Zbornik radova Naučnog instituta za ratarstvo i povrtarstvo Novi Sad 42: 99-107

Maksimović L, Milić S, Červenski J, Pejić B, (2008): Double cropping cabbage after barley. Zbornik radova Instituta za ratarstvo i povrtarstvo 45: 187-193

Matotan Z (2008): Zeljasto povrće. Neron, Bjelovar

Mišković A, Ilin Ž, Marković V, Červenski J (2009): Effect of Substrate type and volume of container cell on quality of Brassica seedlings, Acta Horticulturae 807: 603-606

Republika Srbija (2011): Lista priznatih sorti poljoprivrednog bilja Ministarstva poljoprivrede, trgovine, šumarstva i vodoprivrede. Available at: http://www.sorte.minpolj.gov.rs

Republički zavod za statistiku (2011): Biljna proizvodnja. Available at: http://webrzs.stat.gov.rs/WebSite/

Vučić N (1981): Navodnjavanje i dve žetve godišnje. Dnevnik Štamparija, Novi Sad

\section{Postrna proizvodnja kupusa u Srbiji}

\section{Janko Červenski · Adam Takač}

Izvod: Kupus je značajna povrtarska kultura koja se u Srbiji proizvodi na 20.891 ha. Gajenje kupusa kao druge kulture (tj. postrno) omogućuje intenzivno korišćenje zemljišta i rentabilniju prizvodnju. Kasna ili postrna proizvodnja kupusa u Srbiji ima svoju tradiciju. Relativno često se gaje domaće sorte i populacije kupusa koje definišu i način potrošnje, što je pre svega sveža upotreba, ali i sve prisutnije kišeljenje kupusa. Optimalni rok za rasađivanje kasnog kupusa u agroklimatskim uslovima Srbije je prva polovina jula. Ovaj period karakterišu visoke temperature i nedovoljna količina padavina neravnomernog rasporeda, tako da je proizvodnja kupusa bez navodnjavanja nesigurna. Kod kasnih sorti i hibrida kupusa berba se mora organizovati pre nego što temperatura padne ispod $-5^{\circ} \mathrm{C}$. $\mathrm{Na}-4^{\circ} \mathrm{C} \mathrm{i}-5^{\circ} \mathrm{C}$ kupus može da bude samo privremeno, jer posle dužeg vremena dolazi do izmrzavanja i gubljenja tržišne vrednosti glavica kupusa. Ključne reči: gajenje, kupus, postrna proizvodnja 